\title{
Aquaculture biological waste as culture medium to cultivation of Ankistrodesmus gracilis (Reinsch) Korshikov
}

\author{
L. H. Sipaúba-Tavares ${ }^{*}$, T. Florêncio ${ }^{a}$ and B. Scardoeli-Truzzi ${ }^{a}$ \\ ${ }^{a}$ Centro de Aquicultura, Universidade Estadual Paulista — UNESP, Via de Acesso Prof. Paulo Donato Castellane, s/n, \\ CEP 14884-900, Jaboticabal, SP, Brazil \\ *e-mail: sipauba@caunesp.unesp.br
}

Received: February 6, 2017 - Accepted: March 31, 2017 - Distributed: October 31, 2018

(With 3 figures)

\begin{abstract}
Current study investigated the effectiveness of different macrophytes as culture media for Ankistrodesmus gracilis in laboratory conditions. Significant difference $(\mathrm{p}<0.05)$ was reported in cell density with regard to conventional culture medium $\left(\mathrm{CHU}_{12}\right)$ and macrophytes culture media. Mean cell density in NPK, Eichhornia crassipes and E. azurea media was higher $(\mathrm{p}<0.05)$ than in conventional culture medium. Chlorophyll- $a$ was higher than $1 \mathrm{~g} . \mathrm{L}^{-1}$, except in $\mathrm{CHU}_{12}\left(0.7 \pm 0.4 \mathrm{~g} . \mathrm{L}^{-1}\right)$ and $T$. domingensis $\left(0.8 \pm 0.3 \mathrm{~g} . \mathrm{L}^{-1}\right)$ media. Nitrate decreased sharply as from the $7^{\text {th }}$-day of the experiment. Ammonium and total phosphorus were highest in culture media and ranged between 0.4 g.L $\mathrm{L}^{-1}$ (P. cordata medium) and 1.7 g.L.- $\left(\mathrm{CHU}_{12}\right.$ medium) for ammonium, and between 0.8 g.L.- $\left(\mathrm{CHU}_{12}\right.$ medium $)$ and 1.9 g.L. $\mathrm{L}^{-1}$ (T. domingensis medium) for total phosphorus. Results revealed inorganic fertilizer and macrophytes combined with vitamins may be effective as culture media and strongly supports the growth of Ankistrodesmus gracilis, since cell density and biochemical composition are similar to or higher than conventional culture medium $\left(\mathrm{CHU}_{12}\right)$. Macrophyte is a tool for aquaculture since biological wastes may be used with nutrients to improve the cultivation of microalgae.
\end{abstract}

Keywords: aquatic plants, culture media, microalgae growth, biochemical composition.

\section{Resíduos biológicos de aquicultura como meio de cultura para o cultivo de Ankistrodesmus gracilis (Reinsch) Korshikov}

\section{Resumo}

O presente estudo investigou a eficácia na utilização de diferentes macrófitas como meio de cultura para Ankistrodesmus gracilis em condições laboratoriais. Foi observada diferença significativa $(\mathrm{p}<0,05)$ entre a densidade celular em relação aos meios de cultura convencional $\left(\mathrm{CHU}_{12}\right)$ e de macrófitas. Os meios de cultura com Eichhornia crassipes, E. azurea e NPK apresentaram densidade celular maiores $(\mathrm{p}<0,05)$ que o meio de cultura convencional. Os teores de clorofila- $a$ foram superiores a 1 g. $\mathrm{L}^{-1}$, exceto nos meios de cultura $\mathrm{CHU}_{12}\left(0.7 \pm 0.4\right.$ g. $\left.\mathrm{L}^{-1}\right)$ e de $T$. domingensis $\left(0.7 \pm 0.3\right.$ g. $\left.\mathrm{L}^{-1}\right)$. O nitrato diminuiu acentuadamente a partir do $7^{\circ}$ dia de experimento. Dentre os nutrientes, amônia e o fósforo total foram os mais elevados nos meios de cultura, variando entre 0.4 g.L.-1 (meio de P. cordata) a 1,7 g.L.- (meio CHU ${ }_{12}$ ) para amônia e, entre 0.8 g.L.- (meio $\mathrm{CHU}_{12}$ ) e $1,9 \mathrm{gL}^{-1}$ (meio de T. domingensis) para o fósforo total. Os resultados do presente estudo mostraram que o uso de fertilizantes inorgânicos e macrófitas, combinados com vitaminas, pode ser eficaz como meio de cultura no crescimento de Ankistrodesmus gracilis, uma vez que a densidade celular e a composição bioquímica foram semelhantes ou superiores ao meio de cultura convencional $\left(\mathrm{CHU}_{12}\right)$. As macrófitas são ferramentas a serem adotadas na aquicultura, desde que os resíduos biológicos podem ser usados como nutrientes para melhorar o cultivo de microalgas.

Palavras-chave: plantas aquáticas, meio de cultura, crescimento de microalga, composição bioquímica.

\section{Introduction}

Aquaculture produces large quantities of aquatic organisms with the primary purpose of consumption. In fact, great amounts of organic and inorganic matter generate wastes rich in nitrogen and phosphorus that enhance the growth and invasion of aquatic macrophytes in fishponds. This type of invasion is common in the southeastern region of Brazil due to large fishponds, with macrophytes forming beds of aquatic plants. The use of biological wastes has been carried out mainly in effluent treatment (wetlands) and as a culture medium for microalgae. Macrophyte culture medium with Eichhornia crassipes has shown high growth and protein content of Ankistrodesmus 
gracilis when compared to conventional culture medium (Sipaúba-Tavares et al., 2009, 2011).

The production of natural food, such as microalgae, is commonly accompanied by high financial investments, often attributed to the high costs of the culture medium. Moreover, these culture media are highly specialized and sometimes difficult to obtain on the local markets. However, efforts have been made to find alternative media for microalgae culture which include macrophytes (Sipaúba-Tavares et al., 2009, 2011, 2015) and inorganic fertilizers (Campaña-Torres et al., 2012; El-Nabris, 2012; Martinez-Córdova et al., 2012; Ramaraj et al., 2015; Sipaúba-Tavares and Pereira, 2008). Macrophytes have dominant and supporting roles in nitrogen and phosphorus recovery. Besides the direct assimilation of nitrogen and phosphorus, their roots provide colonizing sites and exude carbohydrates, sugar, amino acids, enzymes and many other compounds. In fact, they exert considerable influence dynamics of nutrients (Polomski et al., 2007).

Nitrogen compounds (ammonia, nitrate and nitrite) are major contaminants in aquaculture waste water. Toxic effects in the water include impairment of physiological parameters, such as, growth rate, oxygen consumption and disease resistance in fish species. However, macrophytes contribute towards nutrient transformation by removing these compounds for their own growth (Sirakov et al., 2015). It is well-known that nitrogen and phosphorus are essential compounds to increment the cultivation of microalgae, and when the medium is obtained for culturing microalgae, it has a direct influence on biological activity for high cell density; and on the metabolic process related to carbon fixation and energy transfer (Grabski and Tukaj, 2008; Singh et al., 2015).

There has recently an increasing interest in the culture of microalgae because it represents a valuable source of various natural products with diverse applications, such as, food industry, biodiesel sources, cosmetic industry, vegetal oils, fish feed, vitamin E, pigments and others. All these factors are directly correlated with the culture medium, because it supports the growth and development of microalgae (Arumugam et al., 2013). Microalgae media, which depend on trace minerals, vitamins (mainly $\mathrm{B}_{12}$, biotin and thiamin), nutrient composition, nitrogen and phosphorus, are compounds that may be added to the culture medium (Shah et al., 2003).

High costs in microalgae cultivation have triggered efforts to find a cheaper and economically feasible approach for microalgae culture. Alternative strategies, aimed at decreasing costs without affecting production should analysed. Current study investigates the effectiveness different macrophytes as culture media for Ankistrodesmus gracilis in laboratory conditions.

\section{Methods}

\subsection{Microalgae culture and laboratory conditions}

Ankistrodesmus gracilis strain was obtained from culture collection n. $005 \mathrm{CH}$, originally from Broa Reservoir, Brazil at $22^{\circ} 15^{\prime} \mathrm{S}$ and $47^{\circ} 19^{\prime} \mathrm{W}$. The algae were batch cultured at
$22 \pm 2^{\circ} \mathrm{C}$, exposed to light at $60 \mu \mathrm{mol} . \mathrm{m}^{-2} . \mathrm{s}^{-1}$ on a 24 -h light cycle, and bubbled with air. So that the effects of different media on the growth of $A$. gracilis could be analyzed, six culture media were employed: a conventional $\mathrm{CHU}_{12}$ medium microalgae cultured in pure nutritive medium was the control, and five alternative media, or rather, one with inorganic fertilizer (NPK 20-5-20) (Sipaúba-Tavares and Rocha, 1993) and four macrophytes culture media. Macrophytes comprised: Eichhornia crassipes, E. azurea, Typha domingensis and Pontederia coradata, with great available on the site. Table 1 shows ingredients and composition of nutrients in the culture media. The effects of six different culture media on the growth of $A$. gracilis were simultaneously investigated during a 28 -days cultivation period with experiments performed under the same growth conditions. The culture media with different macrophytes were based in Sipaúba-Tavares et al. (2009) that used E. crassipes with aquatic plant. Approximately $5 \mathrm{~kg}$ of each plant were ground and boiled in distilled water for one hour. The hot extract was filtered and autoclaved at $120^{\circ} \mathrm{C}$ during 20 minutes. A $70 \mathrm{~mL}$ sample was collected and, after cooling it was diluted with distilled water up to $1.4-\mathrm{L}$ when $2.5 \mathrm{~mL} \mathrm{NPK}$ were added. The experiment started with $10 \mathrm{~mL}$ at a density of $3.5 \times 10^{5}$ cells. $\mathrm{mL}^{-1}$ containing NPK medium. When cultures reached the last exponential growth phase (7-days), approximately $10 \mathrm{~mL}$ with density $1.9 \times 10^{5}$ cells. $\mathrm{mL}^{-1}$ were added to the 2-L NPK medium. After the 7-day exponential growth phase, the culture density $0.75 \times 10^{5}$ cells. $\mathrm{mL}^{-1}$ was transferred to 2-L sterilized recipients containing the six different media (NPK, $\mathrm{CHU}_{12}$ and macrophytes: $\mathrm{Ec}=$ Eichhornia crassipes; Ea=Eichhornia azurea $\mathrm{Td}=$ Typha domingensis; $\mathrm{Pc}=$ Pontederia cordata $)$. Vitamin B complex was added to the alternative culture media at the rate of $0.02 \mathrm{~g} . \mathrm{L}^{-1}$ plus biotin $\left(0.01 \mathrm{mg} . \mathrm{L}^{-1}\right)$. The samples were analysed weekly $(1,7,14,21,28$ days) during the study period, for growth performance and other physiological parameters by the analytical method, except plants biomass.

\subsection{Growth performance}

Cell growth was monitored for 28-days. Triplicate $1 \mathrm{~mL}$ aliquots were removed daily from the microalgae culture and a minimum of $2 \times 1 \mu \mathrm{L}$ sub-samples were used for cell quantification by a Neubauer hemocytometer. Growth rate (k) was calculated by the formula: $\mathrm{k}=\left(3.322 / \mathrm{t}_{2}-\mathrm{t}_{1} \times \log \mathrm{N}_{2} / \mathrm{N}_{1}\right)$ $(\mathrm{t}=$ time; $\mathrm{N}=$ number of cells; subscripts denote values at different times) (Guillard, 1973). Doubling time (cell division time or generation time) was calculated from results obtained from growth rate, by the formula: $\mathrm{Td}=1 \mathrm{k}^{-1}\left(\mathrm{Td}=\right.$ duplication time, $1 \mathrm{k}^{-1}=$ days per division $)$ (Guillard, 1973). Total length of 50 specimens was determined with microscope Leica DFC 295 with image analysis system LAS core (LAS V3.8), and 40X micrometric objective. Cell volume was calculated by mean cell size with the use of the most appropriate geometric form, or rather two coupled cones formula (Hillebrand et al., 1999). Total organic carbon (TOC) was calculated by $\mathrm{C}=0.1204$. 
Table 1. Nutrient composition ( $\left.\mathrm{g} . \mathrm{L}^{-1}\right)$ of different culture media: $\mathrm{NPK} ; \mathrm{CHU}_{12}$ and macrophytes $(\mathrm{Ec}=$ Eichhornia crassipes; $\mathrm{Ea}=$ Eichhornia azurea $; \mathrm{Td}=$ Typha domingensis $; \mathrm{Pc}=$ Pontederia cordata $)$.

\begin{tabular}{|c|c|c|c|c|c|c|}
\hline \multirow{2}{*}{$\begin{array}{c}\text { Nutrient } \\
\text { Composition } \\
\end{array}$} & \multicolumn{6}{|c|}{ Culture Media } \\
\hline & NPK & $\mathrm{CHU}_{12}$ & Ec & $* \mathbf{E a}$ & *Td & $* \mathbf{P c}$ \\
\hline $\mathrm{P}_{2} \mathrm{O}_{5}$ & 2.5 & - & - & - & - & - \\
\hline $\mathrm{K}_{2} \mathrm{O}$ & 10 & - & - & - & - & - \\
\hline $\mathrm{N}$ & 10 & - & 35.1 & 28.4 & 69.9 & 21.5 \\
\hline $\mathrm{P}$ & - & - & 56.4 & 70.7 & 32.0 & 42.8 \\
\hline $\mathrm{K}$ & - & - & 73.0 & 76.2 & 63.0 & 42.4 \\
\hline $\mathrm{Ca}$ & - & - & 0.0369 & 0.0688 & 0.0431 & 0.0621 \\
\hline $\mathrm{Mg}$ & - & - & 0.0023 & 0.0043 & 0.0027 & 0.0038 \\
\hline $\mathrm{S}$ & & & 0.00003 & 0.00003 & 0.00040 & 0.00003 \\
\hline $\mathrm{B}$ & & & 0.00034 & 0.00041 & 0.00053 & 0.00041 \\
\hline $\mathrm{Cu}$ & - & - & 0.00018 & 0.00022 & 0.00028 & 0.00022 \\
\hline $\mathrm{Fe}$ & - & - & 0.00006 & 0.00056 & 0.00073 & 0.00066 \\
\hline $\mathrm{Zn}$ & & & 0.00003 & 0.00012 & 0.00038 & 0.00002 \\
\hline Thiamine & 0.007 & - & 0.007 & 0.007 & 0.007 & 0.007 \\
\hline Vit $B_{2}$ & 0.007 & - & 0.007 & 0.007 & 0.007 & 0.007 \\
\hline Vit $\mathrm{B}_{6}$ & 0.005 & - & 0.005 & 0.005 & 0.005 & 0.005 \\
\hline Vit $B_{12}\left(\mu \mathrm{g} \cdot \mathrm{L}^{-1}\right)$ & 33 & - & 33 & 33 & 33 & 33 \\
\hline $\operatorname{Biotin}\left(\mathrm{mg} . \mathrm{L}^{-1}\right)$ & 0.01 & - & 0.01 & 0.01 & 0.01 & 0.01 \\
\hline $\mathrm{Ca}\left(\mathrm{NO}_{3}\right)_{2}$ & - & 3.0 & - & - & - & - \\
\hline $\mathrm{Na}_{2} \mathrm{CO}_{3}$ & - & 2.0 & - & - & - & - \\
\hline $\mathrm{KCl}$ & - & 0.5 & - & - & - & - \\
\hline $\mathrm{MgSO}_{4} 7 \mathrm{H}_{2} \mathrm{O}$ & - & 7.5 & - & - & - & - \\
\hline $\mathrm{K}_{2} \mathrm{HPO}_{4}$ & - & 0.5 & - & - & - & - \\
\hline $\mathrm{FeCl}_{3} 6 \mathrm{H}_{2} \mathrm{O}$ & - & 0.5 & - & - & - & - \\
\hline
\end{tabular}

*The composition of macrophyte culture was based according Sipaúba-Tavares et al. (2009).

$\mathrm{V}^{1.051}\left(\mathrm{C}=\right.$ carbon content in pg.cell ${ }^{-1} ; \mathrm{V}=$ cell volume $)$ using regression following Rocha and Duncan (1985).

\subsection{Parameters of culture media}

Physical and chemical parameters of culture media were performed weekly. Dissolved oxygen, $\mathrm{pH}$ and conductivity of culture media were measured with YSI 556 MPS multi-sensor. Total phosphorous and nitrogen compounds were quantified spectrophotometry, following Golterman et al. (1978) and Koroleff (1976). Chlorophyll- $a$ was extracted with alcohol $90 \%$ and quantified at $663 \mathrm{~nm}$ and 750nm (Nusch, 1980). Analyses were performed immediately after sampling or samples were duly stored under refrigeration.

\subsection{Biomass of Ankistrodesmus gracilis}

The biomass of microalgae was harvested, centrifuged and lyophilized for the analysis of proteins and lipids (AOAC, 1990). Analyses of macro-minerals (N, P, K, Ca, Mg and S) and micro-nutrients $(\mathrm{B}, \mathrm{Cu}, \mathrm{Fe}, \mathrm{Mn}$, and $\mathrm{Zn}$ ) of microalgae biomass were performed weekly according to methodology by Bataglia et al. (1983).

\subsection{Composition of plant's nutrients}

Dry and wet mass of macrophytes was retrieved and dried at $60{ }^{\circ} \mathrm{C}$ until constant weight and weighted. The composition of the nutrients of aquatic plants was analysed following Bataglia et al. (1983).

\subsection{Data analysis}

All data underwent one-way analysis of variance (ANOVA) with Statistica 8.0 package, to test the effects of the culture media (Statsoft, 2007). When differences between culture media occurred Tukey's test was applied. Differences were considered significant at $\mathrm{p}<0.05$. All results were expressed as means \pm SD (standard deviation) and all experiments were carried out in triplicate.

\section{Results}

Cell concentration of Ankistrodesmus gracilis in alternative media reached maximum cell density at the end of the experiment with $43 \times 10^{6}$ cell. $\mathrm{mL}^{-1}$ on the $27^{\text {th }}$ day in the culture medium NPK, with $43 \times 10^{6}$ cell. $\mathrm{mL}^{-1}$ on the $28^{\text {th }}$

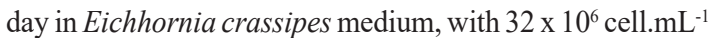
on the $28^{\text {th }}$ day in E. azurea medium, with $29 \times 10^{6}$ cell. 
$\mathrm{mL}^{-1}$ on the $27^{\text {th }}$ day in Typha domingensis medium, with $28 \times 10^{6}$ cell. $\mathrm{mL}^{-1}$ on the $27^{\text {th }}$ day in Pontederia cordata medium (Figure 1). In the case of the conventional medium $\left(\mathrm{CHU}_{12}\right)$, maximum cell density of $\mathrm{A}$. graclis in the culture medium occurred on the $18^{\text {th }}$ day with
$30 \times 10^{6}$ cell.mL $\mathrm{mL}^{-1}$. Lowest cell density $(\mathrm{p}<0.05)$ was reached between the macrophyte media Pontederia cordata and Typha domingensis, albeit similar $(\mathrm{p}>0.05)$ to conventional medium (Figure 1, Table 2). Mean cell density in E. crassipes and NPK media reached a higher
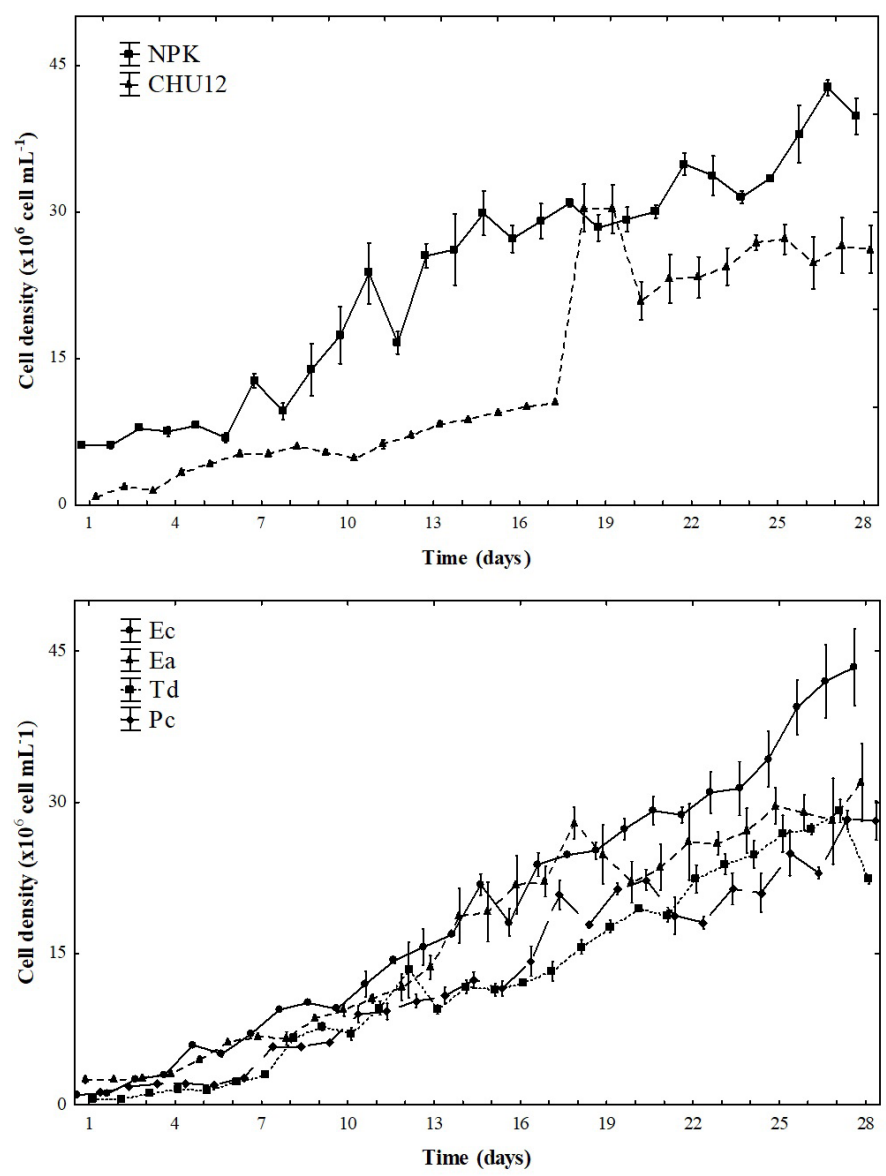

Figure 1. Daily concentration of Ankistrodesmus gracilis cultured in NPK, $\mathrm{CHU}_{12}$ and macrophytes media, where: $\mathrm{Ec}=$ Eichhornia crassipes $; \mathrm{Ea}=$ Eichhornia azurea $; \mathrm{Td}=$ Typha domingensis $; \mathrm{Pc}=$ Pontederia cordata .

Table 2. Production parameters of Ankistrodesmus gracilis cultured in $\mathrm{NPK}, \mathrm{CHU}_{12}$ and macrophytes media, where: $\mathrm{Ec}=$ Eichhornia crassipes $; \mathrm{Ea}=$ Eichhornia azurea $; \mathrm{Td}=$ Typha domingensis $; \mathrm{Pc}=$ Pontederia cordata . The values are the mean of three replications and variation $( \pm)$ is standard deviation.

\begin{tabular}{|c|c|c|c|c|c|c|}
\hline \multirow{2}{*}{ Parameters } & \multicolumn{6}{|c|}{ Culture Media } \\
\hline & NPK & $\mathrm{CHU}_{12}$ & Ec & $* \mathbf{E a}$ & $* \mathbf{T d}$ & $*$ Pc \\
\hline Total length $(\mu \mathrm{m})$ & $18 \pm 2.5^{\mathrm{a}}$ & $15 \pm 2.7^{\mathrm{ab}}$ & $14 \pm 2.5^{b}$ & $15 \pm 1.8^{\mathrm{b}}$ & $14 \pm 2^{b}$ & $14 \pm 1^{b}$ \\
\hline Growth rate $(\mathrm{k})$ & 0.11 & 0.31 & 0.20 & 0.14 & 0.22 & 0.17 \\
\hline Doubling time (days) & 9.3 & 3.3 & 5 & 7.4 & 4.6 & 5.7 \\
\hline Mean cell density $\left(\mathrm{x} 10^{6} . \mathrm{mL}^{-1}\right)$ & $23 \pm 12^{\mathrm{a}}$ & $14 \pm 10^{\mathrm{c}}$ & $19 \pm 13^{\mathrm{ab}}$ & $17 \pm 10^{\mathrm{ab}}$ & $13 \pm 9^{c}$ & $13 \pm 9^{c}$ \\
\hline Maximum cell density $\left(\mathrm{x} 10^{6} . \mathrm{mL}^{-1}\right)$ & $43 \pm 2^{\mathrm{a}}$ & $30 \pm 6^{\mathrm{b}}$ & $43 \pm 9.5^{\mathrm{a}}$ & $32 \pm 9.6^{\mathrm{b}}$ & $29 \pm 2.8^{c}$ & $28 \pm 4.8^{c}$ \\
\hline Cell volume $\left(\mu \mathrm{m}^{3}\right)$ & $57 \pm 28^{\mathrm{ab}}$ & $68 \pm 35^{\mathrm{a}}$ & $20 \pm 5^{c}$ & $22 \pm 7^{c}$ & $23 \pm 3^{c}$ & $23 \pm 3^{c}$ \\
\hline TOC (pg.cell-1 $)$ & $8.5 \pm 4^{\mathrm{ab}}$ & $10 \pm 6^{\mathrm{a}}$ & $2.8 \pm 1^{\mathrm{c}}$ & $3.1 \pm 1^{\mathrm{c}}$ & $3.2 \pm 0.4^{\mathrm{c}}$ & $3.3 \pm 0.4^{\mathrm{c}}$ \\
\hline Chlorophyll- $a\left(\mathrm{~g} . \mathrm{L}^{-1}\right)$ & $1.6 \pm 0.8^{\mathrm{b}}$ & $0.7 \pm 0.3^{\mathrm{d}}$ & $1.3 \pm 0.7^{\mathrm{c}}$ & $1.6 \pm 0.6^{\mathrm{b}}$ & $0.8 \pm 0.2^{\mathrm{d}}$ & $1.9 \pm 0.6^{\mathrm{a}}$ \\
\hline
\end{tabular}

*The composition of macrophyte culture was based according Sipaúba-Tavares et al. (2009). 
mean cell density $(\mathrm{p}<0.05)$ than conventional medium (Figure 1, Table 2).

Constant speed for $A$. gracilis was highest $(\mathrm{p}<0.05)$ in $\mathrm{CHU}_{12}(\mathrm{~K}=0.31)$, whilst between alternative media were highest in $T$. domingensis $(\mathrm{K}=0.22)$ and $E$. crassipes $(\mathrm{K}=0.20)$ and lowest in NPK $(\mathrm{K}=0.11)$ medium (Table 2$)$. Chlorophyll- $a$ contents were higher than 1 g.L.-1 except in $\mathrm{CHU}_{12}\left(0.6 \pm 0.3\right.$ g. $\left.\mathrm{L}^{-1}\right)$ and $T$. domingensis $\left(0.7 \pm 0.3\right.$ g. $\left.\mathrm{L}^{-1}\right)$ media. Total length was greater $(\mathrm{p}<0.05)$ in NPK and in
$\mathrm{CHU}_{12}$ media than in macrophyte media. Cell volume and total organic carbon contents were higher $(p<0.05)$ in NPK and $\mathrm{CHU}_{12}$, and similar $(\mathrm{p}>0.05)$ between macrophyte media (Table 2).

Protein content was similar $(p>0.05)$ between culture media, whilst protein contents of macrophyte media decreased throughout the analyzed period with highest contents on the $7^{\text {th }}$ day ranging between $48 \%$ (T. domingensis and NPK media) and $43 \%$ (P. cordata medium) of dry
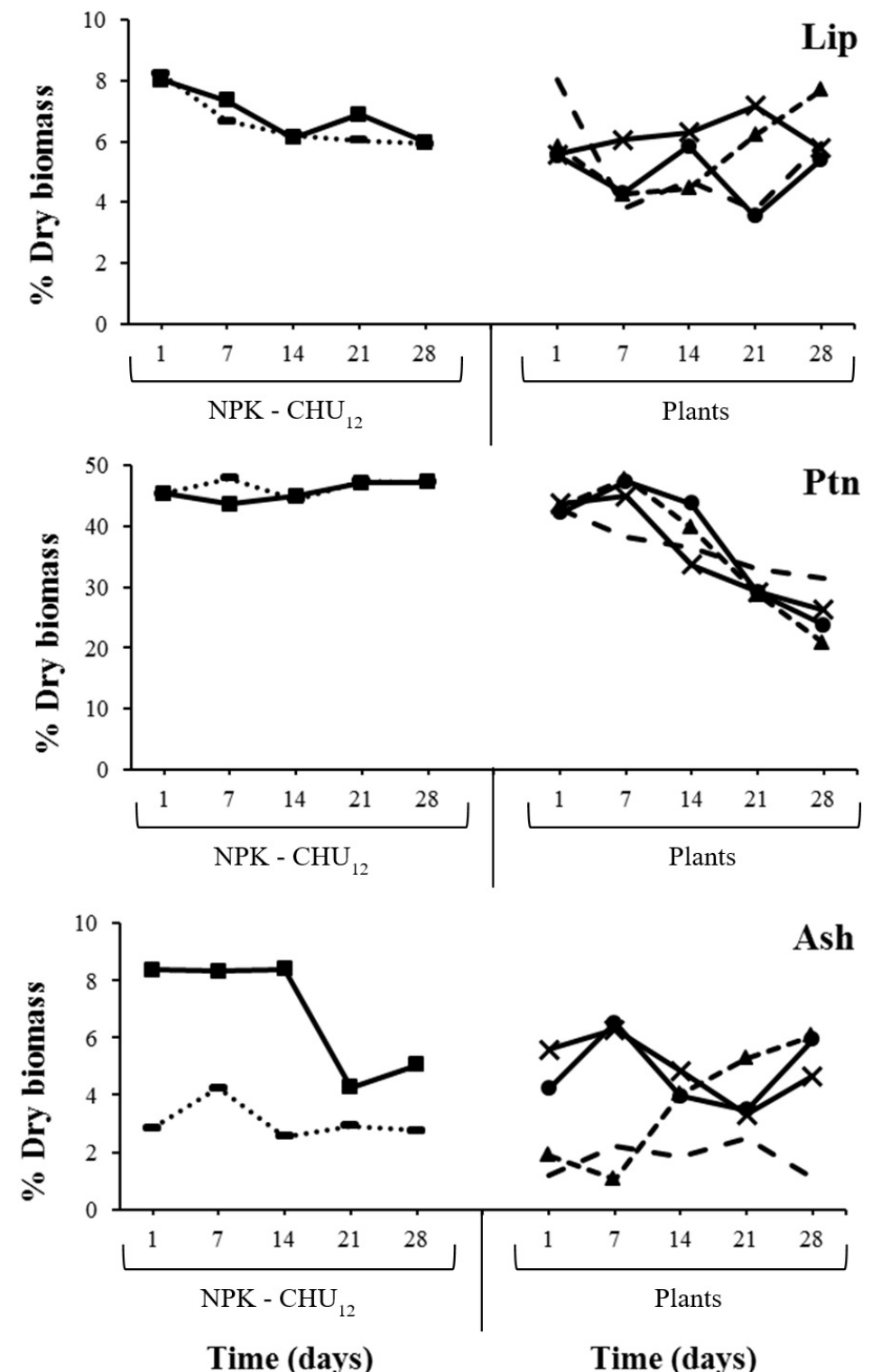

$\cdots-\cdot \mathrm{NPK} \rightarrow \mathrm{CHU12} \rightarrow \mathrm{Ec} \rightarrow \mathrm{Ea}-\leadsto-\mathrm{Td}--\mathrm{Pc}$

Figure 2. Chemical proximate composition of Ankistrodesmus gracilis cultured in NPK, $\mathrm{CHU}_{12}$ and macrophyte media, where: $\mathrm{Ec}=$ Eichhornia crassipes $; \mathrm{Ea}=$ Eichhornia azurea $; \mathrm{Td}=$ Typha domingensis $; \mathrm{Pc}=$ Pontederia cordata $;$ Lip $=1$ lipid; $\mathrm{Ptn}=$ protein . 
biomass. Lipids were below $8.2 \%$ of dry biomass, but similar $(p>0.05)$ between culture media. Ash content was higher in $\mathrm{CHU}_{12}$ medium (8.4 pg.cell ${ }^{-1}$ dry biomass) until the $14^{\text {th }}$ day and similar among E. crassipes, E. azurea and T. domingensis media. However, the lowest contents were reached in NPK and $P$. cordata media, ranging between 1.1 and 5.6 pg.cell $^{-1}$ of dry biomass (Figure 2).

Differences $(p<0.05)$ of water parameters of culture media were registered. As a rule, $\mathrm{pH}$ was alkaline except in the beginning of the experiment (Figure 3). Constant air bubbling of culture medium showed dissolved oxygen above $5.4 \mathrm{mg} . \mathrm{L}^{-1}$ and ranging conductivity between $295 \pm 57 \mu{\mathrm{S} . \mathrm{cm}^{-1}}^{-1}$ $P$. cordata medium and 1,609 $\pm 117 \mu \mathrm{S} \mathrm{cm}^{-1}$ in NPK medium. In case of nitrogen compounds, ammonium was higher $(\mathrm{p}<0.01)$ in the culture media, ranging between $0.4 \pm 0.2$ g.L L $^{-1}$ (E. azurea) and $1.3 \pm 0.2$ g.L L $^{-1}$ (E. crassipes). Nitrate decreased sharply after the $7^{\text {th }}$ day of the experiment. Total phosphorus was highest in the culture media between $0.8 \mathrm{~g} . \mathrm{L}^{-1}\left(\mathrm{CHU}_{12}\right.$ medium), and 1.9 g.L $\mathrm{L}^{-1}$ (T. domingensis medium) (Figure 3).

High nitrogen compounds and total phosphorus in the culture media are due to concentrations of nutrients in the inorganic fertilizer and aquatic plants. The composition of nutrients mainly nitrogen and potassium, in the plants was high ranged between $6.5 \mathrm{~g} \cdot \mathrm{kg}^{-1}$ (P. cordata medium) and $24 \mathrm{~g} \cdot \mathrm{kg}^{-1}$ (E. crassipes medium). However, calcium was above $5.4 \mathrm{~g} . \mathrm{kg}^{-1}$. The highest
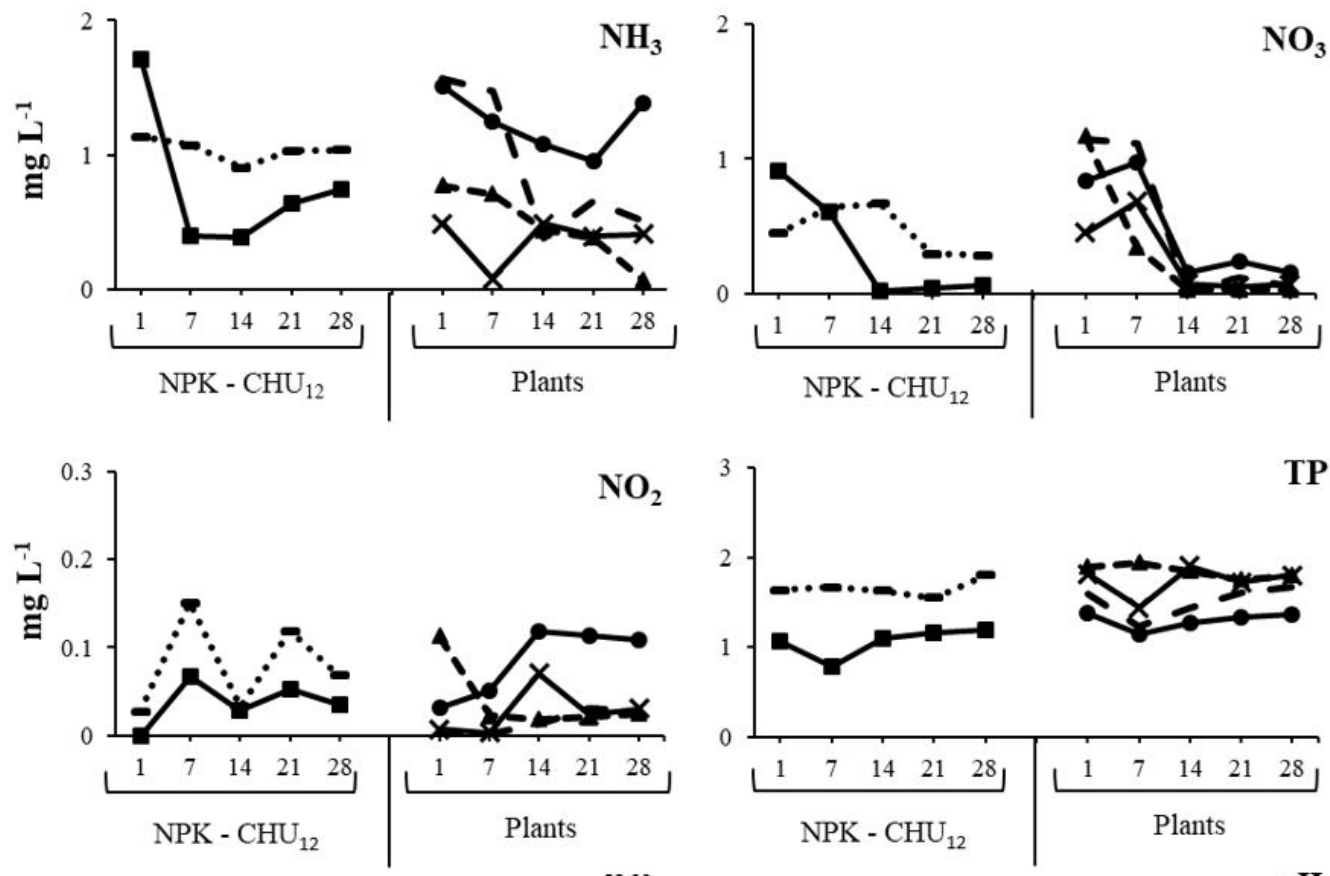

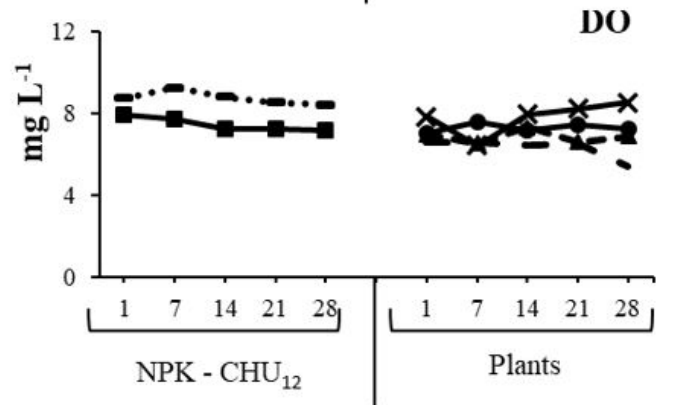

Time (days)

Time (days)

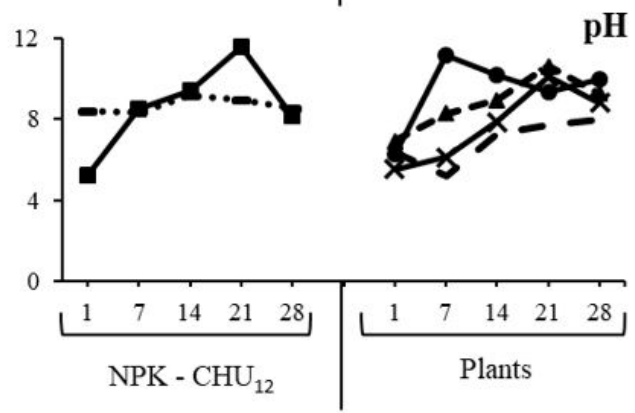

Time (days)

Time (days)
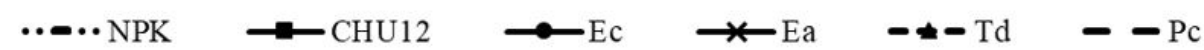

Figure 3. Weekly variation of ammonium $\left(\mathrm{NH}_{4}\right)$; nitrate $\left(\mathrm{NO}_{3}\right)$; nitrite $\left(\mathrm{NO}_{2}\right)$, total phosphorus $(\mathrm{TP})$, dissolved oxygen $(\mathrm{DO})$ and $\mathrm{pH}$ in the different media $\left(\mathrm{NPK}, \mathrm{CHU}_{12}\right.$ and macrophytes media), where: $\mathrm{Ec}=$ Eichhornia crassipes; Ea = Eichhornia azurea $; \mathrm{Td}=$ Typha domingensis $; \mathrm{Pc}=$ Pontederia cordata . 
Table 3. Nutrient composition and dry and wet biomass $\left(\mathrm{g} \cdot \mathrm{kg}^{-1}\right)$ of plants, where: $\mathrm{Ec}=$ Eichhornia crassipes; Ea = Eichhornia azurea $; \mathrm{Td}=$ Typha domingensis; $\mathrm{Pc}=$ Pontederia cordata .

\begin{tabular}{ccccc}
\hline Nutrient & \multicolumn{3}{c}{ Plants } \\
\cline { 2 - 5 } Composition & Ec & Ea & Td & Pc \\
\hline Boron (B) & 0.01 & 0.03 & 0.02 & 0.01 \\
Calcium (Ca) & 7 & 7.2 & 5.4 & 5.7 \\
Copper (Cu) & 0.02 & 0.04 & 0.01 & 0.05 \\
Iron (Fe) & 3 & 2.7 & 2.3 & 3.3 \\
Magnesium (Mg) & 3.2 & 2.7 & 1.8 & 1.1 \\
Manganese (Mn) & 1.5 & 0.3 & 0.5 & 0.5 \\
Nitrogen (N) & 24 & 9.8 & 12.4 & 10.1 \\
Phosphorus (P) & 3.3 & 1.8 & 2 & 1.8 \\
Potassium (K) & 24 & 14.1 & 17.2 & 6.5 \\
Sulfur (S) & 3.8 & 0.9 & 0.7 & 4.4 \\
Zinc (Zn) & 0.2 & 0.1 & 0.1 & 0.1 \\
Wet mass & 5 & 5 & 5 & 5 \\
Dry mass & 1,148 & 1,039 & 996 & 1,012 \\
\hline
\end{tabular}

plant nutrients occurred in Eichhornia. In general, the plants nutrients composition was over 0.1 g. $\mathrm{kg}^{-1}$, whilst boron and copper concentrations in the plants were below 0.05 g. $\mathrm{kg}^{-1}$. Wet mass was similar between plants and dry mass ranging between 996 g. $\mathrm{kg}^{-1}$ in Typha domingensis medium and 1,148 g. $\mathrm{kg}^{-1}$ in E. crassipes medium (Table 3).

\section{Discussion}

The use of inorganic fertilizer NPK (20-5-20) and floating macrophytes provide more efficient growth rate and nutritional values than conventional medium $\left(\mathrm{CHU}_{12}\right)$. These alternative culture media provide a better possibility to replace the conventional culture medium, more expensive and less accessible to consumers when compared to inorganic fertilizer (NPK) and to macrophytes. Therefore it may be hypothesized that the use of floating macrophytes and inorganic fertilizer (NPK, 20-5-20) could provide similar or better results at lower costs. Martinez-Córdova et al. (2012) used agricultural fertilizer and obtained similar proximate composition of Chaetoceros muelleri when compared to conventional culture medium (Guillard F/2). These results are consistent with the $A$. gracilis experiment where mean cell density in NPK medium at $23 \times 10^{6}$ cell. $\mathrm{mL}^{-1}$ and maximum cell density at $43 \times 10^{6}$ cell. $\mathrm{mL}^{-1}$ were higher than conventional culture medium $\left(\mathrm{CHU}_{12}\right)$.

Results of current study indicated great variations in cell density during the study period. Since nitrogen is a major nutrient for microalgae cultivation, difference may be due to availability and variability of nitrogen sources in the media. It may be due to nitrogen sources ammonium and nitrate in the former media. El Nabris (2012) indicated a positive correlation between nitrogen concentration and cell density of Nannochloropsis sp cultured in agricultural fertilizer, with ammonium as the main source of nitrogen. According to the author, when ammonium is highly concentrated it is consumed faster than nitrate due to inactive nitrate reductase. In current study, nitrate in the culture media decreased faster than ammonium, with ammonium contents above 0.3 g.L. $\mathrm{L}^{-1}$. Maximum growth of freshwater Scenedesmus bijugatus responded well to nitrogen source, such as potassium nitrate, indicating a favourable source for growth (Arumugam et al., 2013). In current study, the culture media with inorganic fertilizer and macrophytes media had the highest contents of nitrogen and potassium, and nitrate contents were consumed fast. These nutrients in the alternative culture media improve mean cell density, chlorophyll- $a$ and maximum cell density that were similar or higher than the conventional culture medium. Chemical proximate composition was similar among all culture media used.

Phosphorus is one of the major nutrients required for the normal growth of microalgae. High total phosphorus contents in the water media directly affect plants due concentration above $1.8 \mathrm{~g} \cdot \mathrm{kg}^{-1}$ and consequently improve microalgae growth. In general, culture media have enough amount of phosphorus for microalgae growth with special reactions associated to cell division (Ramaraj et al., 2015).

Nitrogen deprivation is a severe stress condition for all organisms, since nitrogen is a major constituent of proteins and nucleic acids and a highly abundant atomic species in living cells (Huang et al., 2013). Nitrogen also influences chlorophyll- $a$ high content above 0.3 g.L.- were obtained for $A$. gracilis mainly in the alternative media, except Typha domingensis medium which was similar to the conventional culture medium $\left(\mathrm{CHU}_{12}\right)$. Mutlu et al. (2011) reported a decrease in chlorophyll- $a$ content of Chlorella vulgaris when treated with nitrogen-starvation, featuring a yellowish color in the culture.

Lipid contents lower than $8.2 \%$ of total dry biomass of microalgae in current study is in accordance with the well documented fact that lipid accumulation occurs under limited nitrogen conditions and high iron supplementation. Nitrogen compounds current analysis had higher contents mainly due to inorganic fertilizer and aquatic plants. On the other hand, iron contents were very low in the culture media 
used and in the composition of macrophytes. Singh et al. (2015) contained the highest lipid contents $(59.6 \%)$ for Ankistrodesmus falcatus under moderate nitrogen $\left(750 \mathrm{mg} . \mathrm{L}^{-1}\right)$ and high iron $\left(9 \mathrm{mg} . \mathrm{L}^{-1}\right)$ supplementation. The same authors demonstrated that $\mathrm{N}$ and $\mathrm{Fe}$ have a significant effect on lipid production when compared to phosphorus. Low lipid content in A. gracilis biomass using different alternative media was due to low $\mathrm{Fe}$ (below $0.8 \mathrm{mg} . \mathrm{L}^{-1}$ ), whilst high nitrogen compounds (above 10 g.. $\mathrm{L}^{-1}$ ) in the culture media influenced protein contents and high $A$. gracilis biomass. Msanne et al. (2012) observed that reduction in proteins levels affects photosynthesis and amino acid synthesis which resulted in slow growth and low biomass yield of Chlamydomonas reinhardtii and Coccomyxa sp. A combination of nitrogen deficiency, moderately high light intensity and high Fe level improved lipid accumulation in four strains of Botryococcus sp. (Yeesang and Cheirsilp, 2011). Mata et al. (2013) reported that Dunaliella tertiolecta cultured in medium with Fe showed a higher biomass concentration than with $\mathrm{Mn}$ and $\mathrm{Zn}$. Iron contents in the culture media used in this study were lower but $\mathrm{K}, \mathrm{N}$, and $\mathrm{P}$ contents had the highest nutrient contents in the culture media and influenced the growth of A. gracilis in macrophytes media. Sevaral factors, such as $\mathrm{pH}$, temperature, nitrogen deficiency and phosphorus limitation of culture medium, are known to influence the lipid content of microalgae (Huang et al., 2013).

Water quality of culture media in current study was totally under control and free from pollution. This setup provided an ideal environment for microalgae culture media. According to Shah et al. (2003) alternative media with organic matter have their own limitations and cannot compete with pure nutrients. Further, $\mathrm{pH}$, dissolved oxygen and conductivity were in satisfactory conditions for the growth of $A$. gracilis. In general, $\mathrm{pH}$ was alkaline and the constant mixing of water kept the dissolved oxygen above $5.4 \mathrm{mg} . \mathrm{L}^{-1}$. The increase of $\mathrm{pH}$ during photosynthesis, due to nutrients uptake to consume bi-carbonate; and in the culture media with ideal mixing might optimize microalgae access nutrients and uptake easily the dissolved inorganic carbon (Ramaraj et al., 2015)

Results show that the use of inorganic fertilizer and macrophytes with vitamin solutions may be effective as culture media and strongly support the growth of Ankistrodesmus gracilis, since cell density and biochemical composition were similar to or higher than conventional culture medium $\left(\mathrm{CHU}_{12}\right)$. Further research is necessary to verify the real potential of macrophytes and which plants are more appropriated for cultivation of microalgae. The use of these aquatic plants as culture medium should always be associated with NPK and vitamins. In our case, besides the inorganic fertilizer the floating macrophytes Eichhornia crassipes and E. azzurea showed had the best results for the growth of $A$. gracilis. To balance adverse conditions (appearance of macrophytes) in aquaculture transformation into a high quality product for the growth of microalgae is a tool that may be employed in aquaculture since biological wastes may be used with nutrients to improve microalgae cultivation.

\section{Acknowledgements}

The authors would like to thank FAPESP for its financial support (14/24697-3) and CNPq for the award of a scholarship to the first author (PQ 305343/2014-9) and the second author (130584/2015-0).

\section{References}

ARUMUGAM, M., AGARWAL, A., ARYA, M.C. and AHMED, Z., 2013. Influence of nitrogen sources on biomass productivity of microalgae Scenedesmus bijugus. Bioresource Technology, vol. 131, no. 1, pp. 246-249. PMid:23353039. http://dx.doi. org/10.1016/j.biortech.2012.12.159.

ASSOCIATION OF OFFICIAL ANALYTICAL CHEMISTS - AOAC. Official methods of analysis (15th ed.) Washington, USA: AOAC, 1990.

BATAGLIA, O.C., FURLANI, A.M.C., TEIXEIRA, J.P.F., FURLANI, P.R. and GALLO, J.R., 1983. Chemical analysis methods for plants. Campinas: Instituto Agronômico. 48 p. Boletim Técnico, no. 78 .

CAMPAÑA-TORRES, A., MARTÍNEZ-CORDOVÁ, LR., MARTÍNEZ-PORCHAS, M., LÓPEZ-ELÍAS, JÁ. and PORCHASCORNEJO, MA., 2012. Productive response of Nanochloropsis oculata, cultured in different media and their efficiency as food for the rotifer Brachionus rotundiformis. International Journal of Experimental Botany, vol. 81, pp. 45-50.

EL-NABRIS, K.J.A., 2012. Development of cheap and simple culture medium for the microalgae Nannochloropsis sp. based on agricultural grade fertilizers available in the local market of Gaza stripe (Palestine). Journal of Al Azhar University-Gaza, vol. 14, pp. 61-76.

GOLTERMAN, H.L., CLYMO, R.S. and OHMSTAD, M.A.M., 1978. Methods for physical and chemical analysis of fresh water. 2 ed. Oxford: Blackwell Scientific Publications. 213 p. IBP Handbook, no. 8 .

GRABSKI, K. and TUKAJ, Z., 2008. Auto-induction activity of a conditioned medium obtained from high density cultures of a green alga Scenedesmus subspicatus. Journal of Applied Phycology, vol. 20, no. 3, pp. 323-330. http://dx.doi.org/10.1007/ s10811-007-9260-x.

GUILLARD, R.R.L., 1973. Division rates. In: J.R. STEIN. Handbook of phycological methods. Culture methods and growth measurements. London: Cambridge University Press, pp. 289-311.

HILLEBRAND, H., DÜRSELEN, C.D., KIRSCHTEL, D., POLLINGHER, U. and ZOHARY, T., 1999. Biovolume calculation for pelagic and benthic microalgae. Journal of Phycology, vol. 35, no. 2, pp. 403-424. http://dx.doi.org/10.1046/j.15298817.1999.3520403.x

HUANG, X., HUANG, Z., WEN, W. and YAN, J., 2013. Effects of nitrogen supplementation of the culture medium on the growth, total lipid content and fatty acid profiles of three microalgae (Tetraselmis subcordiformis, Nannochloropsis oculata and Pavlova viridis). Journal of Applied Phycology, vol. 25, no. 1, pp. 129-137. http://dx.doi.org/10.1007/s10811-012-9846-9.

KOROLEFF, F., 1976. Determination of nutrients. In: E. GRASHOF and E. KREMLING, eds. Methods of seawater analysis. German: Verlag Chemie Wenhein, pp. 126-133. 
MARTÍNEZ-CORDOVÁ, L.R., CAMPAÑA-TORRES, A., MARTÍNEZ-PORCHAS, M., LÓPEZ-ELÍAS, J.A. and GARCÍA-SIFUENTES, C.O., 2012. Effect of alternative mediums on production and proximate composition of the microalgae Chaetoceros muelleri as food in culture of the copepod Acartia sp. Latin American Journal of Aquatic Research, vol. 40, no. 1, pp. 169-176. http://dx.doi.org/10.3856/vol40-issue1-fulltext-16.

MATA, T.M., ALMEIDA, R. and CAETANO, N.S., 2013. Effect of the culture nutrients on the biomass and lipid productivities of microalgae Dunaliella tertiolecta. Chemical Engineering Transactions, vol. 32, no. 32, pp. 973-978.

MSANNE, J., XU, D., KONDA, A.R., CASAS-MOLLANO, J.A., AWADA, T., CAHOON, E.B. and CERUTTI, H., 2012. Metabolic and gene expression changes triggered by nitrogen deprivation in the photoautotrophically grown microalgae Chlamydomonas reinhardtii and Coccomyxa sp. C-169. Phytochemistry, vol. 75, no. 1, pp. 50-59. PMid:22226037. http://dx.doi.org/10.1016/j. phytochem.2011.12.007.

MUTLU, Y.B., ISIK, O., USLU, L., KOÇ, K. and DURMAZ, Y., 2011. The effects of nitrogen and phosphorus deficiencies and nitrite addition on the lipid content of Chlorella vulgaris (Chlorophyta). African Journal of Biotechnology, vol. 10, no. 3, pp. 453-456.

NUSCH, E.A., 1980. Comparison of different methods for chorophyll and phaeopigments determination. Archiv für Hydrobiologie, vol. 14, pp. 4-36.

POLOMSKI, R.F., BIELENBERG, D.C. and WHITWELL, T., 2007. Nutrient recovery by seven aquatic garden plants in a laboratory-scale subsurface-constructed wetland. HortScience, vol. 42 , no. 7 , pp. 1674-1680.

RAMARAJ, R., TSAI, D.D.W. and CHEN, P.H., 2015. Carbon dioxide fixation of freshwater microalgae growth on natural water medium. Ecological Engineering, vol. 75, no. 1, pp. 86-92. http:// dx.doi.org/10.1016/j.ecoleng.2014.11.033.

ROCHA, O. and DUNCAN, A., 1985. The relationship between cell carbon and cell volume in freshwater algae species used in zooplankton studies. Journal of Plankton Research, vol. 7, no. 2, pp. 279-294. http://dx.doi.org/10.1093/plankt/7.2.279.

SHAH, M.M.R., ALAM, M.J., ISLAM, M.L. and KHAN, M.S.A., 2003. Growth performance of three microalgae species in filtered brackish water with different inorganic media. Bangladesh Journal of Fisheries Research, vol. 7, no. 1, pp. 69-76.
SINGH, P., GULDHE, A., KUMARI, S., RAWAT, I. and BUX, F., 2015. Investigation of combined effect of nitrogen, phosphorus and iron on lipid productivity of microalgae Ankistrodesmus falcatus KJ671624 using response surface methodology. Biochemical Engineering Journal, vol. 94, pp. 22-29. http://dx.doi.org/10.1016/j. bej.2014.10.019.

SIPAÚBA-TAVARES, L.H. and PEREIRA, A.M.L., 2008. Large scale laboratory cultures of Ankistrodesmus gracilis (Reisch) Korsikov (Chlorophyta) and Diaphanosoma biergei Korinek, 1981 (Cladocera). Brazilian Journal of Biology $=$ Revista Brasileira de Biologia, vol. 68, no. 4, pp. 875-883. PMid:19197508. http:// dx.doi.org/10.1590/S1519-69842008000400025.

SIPAÚBA-TAVARES, L.H. and ROCHA, O., 1993. Large-scale cultivation of plankton for feeding larvae and fish fry: I-Algae green. Biotemas, vol. 6, no. 1, pp. 93-106.

SIPAÚBA-TAVARES, L.H., BERCHIELLI-MORAIS, F.A. and SCARDOELI-TRUZZI, B., 2015. Growth of Haematococcus pluvialis Flotow in alternative media. Brazilian Journal of Biology = Revista Brasileira de Biologia, vol. 75, no. 4, pp. 796-803. PMid:26675899. http://dx.doi.org/10.1590/1519-6984.23013.

SIPAÚBA-TAVARES, L.H., IBARRA, L.C. and FIORESI, T.B., 2009. Ankistrodesmus gracilis (Reinsch) Korshikov (Chlorophyta) laboratory cultured in $\mathrm{CHU}_{12}$ and macrophyte with NPK media. Boletim do Instituto de Pesca, vol. 35, no. 1, pp. 111-118.

SIPAÚBA-TAVARES, L.H., MILLAN, R.N., BERCHIELLI, F.A. and BRAGA, F.M.S., 2011. Use of alternative media and different types of recipients in a laboratory culture of Ankistrodesmus gracilis (Reinsch) Korshikov (Chlorophyta). Acta Scientiarum. Biological Sciences, vol. 33, no. 3, pp. 247-253. http://dx.doi. org/10.4025/actascibiolsci.v33i3.8046.

SIRAKOV, I.K., VELLICHKOVA, K., STOYANOVA, S., DINEV, D. and STAYKOV, Y., 2015. Application of natural zeolites and macrophytes for water treatment in recirculation aquaculture systems. Bulgarian Journal of Agricultural Science, vol. 21, no. 1 , pp. $147-153$.

STATSOFT. 2007. Statistica. Data Analysis Software System, version 8. Tulsa: Statsoft Inc.

YEESANG, C. and CHEIRSILP, B., 2011. Effect of nitrogen, salt, and iron content in the growth medium and light intensity on lipid production by microalgae isolated from freshwater sources in Thailand. Bioresource Technology, vol. 102, pp. 3034-3040. PMID: 20980142. http://dx.doi.org/10.1016/j.biortech.2010.10.013. 